\title{
Analisis Nilai-nilai Karakter pada Buku Siswa Mata Pelajaran Pendidikan Agama Islam dan Budi Pekerti (PAdBP) Kurikulum 2013 Sekolah Dasar
}

\author{
Hasan Hakim ${ }^{1}$ dan Samsul Huda ${ }^{2}$ \\ SDN Bandung Wonosegoro Boyolali dan MIS Kuripan Kidul Pekalongan \\ Surel : hasan.hakim234@gmail.com ${ }^{1}$, wongbyasabae@gmail.com²
}

\begin{abstract}
This study aims to 1) determine the content of character values that appear in the elementary school book 'PAdBP', 2) find out the strategy of five values of strengthening character education in the elementary school book 'PAdBP' based on the thoughts of Thomas Lickona and Ki Hajar Dewantara. This research method uses a qualitative approach with the library research type. Data collection was obtained by reviewing documents, i.e., the elementary students' book namely 'PAdBP'. Data analysis techniques included content analysis and critical analysis. Validity checking of the findings was done by reading through the glasses of educational thinking of the characters of Thomas Lickona and Ki Hajar Dewantara. The results showed that 1) Character values that appear in the student book $P A d B P$ are religious, compassion, caring, responsibility, independent, fond of reading, respect, obedience, honesty, mutual cooperation, sympathy, courage, discipline, trust self, humble, integrity, gratefulness, sincerity, respect, politeness, hard work, clean and healthy life, simplicity, harmonious life, kindness, good saying, forgiving, help, love and peace, ask for help, trust, politeness, never give up, safety, loving beauty, and tolerance values. 2) The strategy of planting five values of character education reinforcement in the elementary school book $P A d B P$ produced percentages that were varied in the volume of emphasis. Religious value was very dominant with a percentage of $31 \%$, the value of mutual cooperation was $24 \%$, independent value was 18\%, integrity value was 17\%, and nationalist value was $10 \%$. Furthermore, the five values of character education reinforcement when analyzed using Thomas Lickona's character education theory showed that some of the contents regarding the learning process in the PAdBP book have not yet been in accordance with the procedure, and when viewed from the educational theory of Ki Hajar Dewantara, the book contents have been fully fulfilled.
\end{abstract}

Keywords: Character Value, Five Character Education Reinforcement Values, PAdBP student book, Thomas Lickona and Ki Hajar Dewantara. 


\begin{abstract}
Abstrak
Penelitian ini bertujuan untuk 1) mengetahui isi nilai karakter yang muncul dalam buku sekolah dasar 'PAdBP', 2) mengetahui strategi lima nilai penguatan pendidikan karakter pada buku sekolah dasar 'PAdBP' berdasarkan pemikiran Thomas Lickona dan Ki Hajar Dewantara. Metode penelitian ini menggunakan pendekatan kualitatif dengan jenis penelitian kepustakaan. Pengumpulan data diperoleh dengan meninjau dokumen, yaitu, buku siswa sekolah dasar yaitu 'PAdBP'. Teknik analisis data meliputi analisis isi dan analisis kritis. Pengecekan validitas temuan dilakukan dengan membaca kacamata pemikiran pendidikan karakter Thomas Lickona dan Ki Hajar Dewantara. Hasil penelitian menunjukkan bahwa 1) Nilai-nilai karakter yang muncul dalam buku siswa PAdBP adalah agama, kasih sayang, kepedulian, tanggung jawab, mandiri, gemar membaca, menghormati, taat, jujur, gotong royong, simpati, keberanian, disiplin, percaya diri, rendah hati, integritas, rasa terima kasih, ketulusan, hormat, kesopanan, kerja keras, hidup bersih dan sehat, kesederhanaan, kehidupan yang harmonis, kebaikan, ucapan baik, memaafkan, membantu, cinta dan kedamaian, meminta bantuan, kepercayaan, kesopanan, tidak pernah menyerah, aman, cinta keindahan, dan nilai-nilai toleransi. 2) Strategi penanaman lima nilai penguatan pendidikan karakter dalam buku sekolah dasar PAdBP menghasilkan persentase yang bervariasi dalam volume penekanan. Nilai agama sangat dominan dengan persentase 31\%, nilai gotong royong adalah 24\%, nilai independen 18\%, nilai integritas $17 \%$, dan nilai nasionalis $10 \%$. Selanjutnya, lima nilai penguatan pendidikan karakter ketika dianalisis menggunakan teori pendidikan karakter Thomas Lickona menunjukkan bahwa beberapa konten mengenai proses pembelajaran dalam buku PAdBP belum sesuai dengan prosedur, dan ketika dilihat dari teori pendidikan Ki Hajar Dewantara, isi buku sudah sepenuhnya terpenuhi.

Kata Kunci : Nilai Karakter, Nilai-Nilai Penguatan Pendidikan Karakter, buku siswa PAdBP, Thomas Lickona dan Ki Hajar Dewantara.
\end{abstract}

\section{A. PENDAHULUAN}

Bangsa Indonesia saat ini masih terus mengalami berbagai persoalan nasional yang tidak mudah untuk diatasi. Seperti masalah korupsi, keadilan sosial, kurangnya penghargaan pada pribadi manusia, daya tahan yang lemah pada orang muda, konflik yang sering memakan korban jiwa, kurangnya perhatian pada warga bangsa yang miskin dan kecil, dan narkoba. ${ }^{1}$ Menanggapi persoalan semacam ini, kementerian pendidikan dan kebudayaan sebagai stakeholder pemerintah telah melakukan usaha nyata dengan langkah inovasi

\footnotetext{
1 Paul Suparno, Pendidikan Karakter Di Sekolah (Yogyakarta: Kanisius, 2015), 134.
}

kurikulum. Kurikulum yang sebelumnya adalah Kurikulum Tingkat Satuan Pendidikan (KTSP) diganti dengan Kurikulum berbasis karakter atau dikenal dengan Kurikulum 20132 .

Pendidikan karakter adalah usaha bersama komunitas sekolah untuk menciptakan lingkungan belajar yang kondusif bagi pertumbuhan dan pembentukan moral tiap individu yang terlibat dalam dunia pendidikan. Mengembangkan dan menumbuhkan individu sebagai pribadi bermoral sesuai dengan apa yang diinginkan, itulah inti

\footnotetext{
${ }^{2}$ Kemendikbud, Hand Out Bahan Pelatihan Materi Umum Dan Materi Pokok Sekolah Dasar (Direktorat Kemendikbud, 2016), 7.
} 
pendidikan karakter ${ }^{3}$. Maka tidak heran pada beberapa dekade tahun terakhir pendidikan karakter mendapatkan tekanan lebih besar dengan penekanan pada Kompetensi Inti (KI) 1 dan 2 tentang ketakwaan dan karakter yang harus ditekankan di sekolah oleh setiap guru lewat mata pelajaran mereka masingmasing ${ }^{4}$. Dengan demikian, dapat diketahui bersama bahwa pada tingkat jenjang sekolah mulai SD/MI, SMP/MTs dan SMA/MA tugas dan tanggungjawab guru agama sedikit banyak terbantukan dengan diberlakukannya kurikulum 2013.

Pemerintah dalam suksesi pendidikan karakter telah mempersiapkan buku ajar yang dapat dimanfaatkan sepenuhnya oleh pendidik maupun peserta didik. Berkaitan dengan buku ajar peserta didik mata pelajaran Pendidikan Agama Islam dan Budi Pekerti (PAdBP) kurikulum 2013 sekolah dasar, koran Republika memberikan sebuah informasi yang isinya adalah Dinas Pendidikan Labuhanbatu Sumatera Utara telah menarik ribuan paket buku ajar siswa mata pelajaran PAdBP kelas III, IV, V dan VI Sekolah Dasar dan Madrasah Ibtidaiyah.

Penarikan buku siswa tersebut terjadi dikarenakan pada cover buku terdapat gambar animasi beberapa orang yang sedang berdiri mengerjakan shalat berjama'ah akan tetapi tata cara bersedekapnya tidak bisa dibenarkan oleh ilmu agama secara umum. Sampul

\footnotetext{
${ }^{3}$ Doni Koesoema, Pendidikan Karakter Utuh Dan Menyeluruh Edisi Revisi (Yogyakarta: PT Kanisius, 2015), 23.

${ }^{4}$ Suparno, Pendidikan Karakter Di Sekolah, 5.
}

buku juga dinilai berpotensi menimbulkan pemahaman yang salah dan berkelanjutan pada diri peserta didik yang pada akhirnya dinilai dapat meresahkan warga masyarakat ${ }^{5}$.

Sebagaimana diketahui bersama bahwa diantara fungsi pokok diterbitkannya buku siswa selain sebagai pegangan dalam melaksanakan proses pembelajaran juga merupakan salah satu bentuk ikhtiar pemerintah dalam menanggulangi degradasi moral peserta didik yang kian marak terjadi. Dari permasalahan yang telah dikemukakan, peneliti tertarik untuk menggali dan menganalisis buku siswa mata pelajaran Pendidikan Agama Islam dan Budi Pekerti (PAdBP) Kurikulum 2013 Sekolah Dasar.

\section{B. METODE PENELITIAN}

Penelitian ini merupakan jenis penelitian deskriptif-kualitatif. Penelitian kualitatif adalah sebuah proses penyelidikan untuk memahami masalah berdasarkan pada penggambaran holistik yang dibentuk dengan kata-kata sekaligus berusaha memahami serta menafsirkan makna suatu teks dalam sebuah latar ilmiah. Sehingga yang menjadi subjek dalam penelitian ini adalah peneliti sendiri dan objeknya ialah buku siswa mata pelajaran Pendidikan Agama Islam dan Budi Pekerti (PAdBP) Sekolah Dasar.

\footnotetext{
5 "Ribuan Buku Pendidikan Agama Islam Ditarik Di Labuhanbatu | Republika Online," accessed September 5, 2019, https://nasional.republika.co.id/berita/onxtnx38 4/ribuan-buku-pendidikan-agama-islam-ditarikdi-labuhanbatu.
} 
Pendekatan yang dipakai dalam penelitian ini adalah menggunakan model pendekatan deskriptif. Pendekatan deskriptif adalah sebuah prosedur pemecahan masalah yang cara kerjanya dengan menggambarkan atau melukiskan keadaan objek penelitian pada saat sekarang, berdasarkan fakta-fakta yang tampak atau sebagaimana adanya ${ }^{6}$. Artinya peneliti harus memberikan gambaran nyata/fakta mengenai analisisnya terhadap objek penelitian yang berupa buku siswa mata pelajaran Pendidikan Agama Islam dan Budi Pekerti (PAdBP) Sekolah Dasar.

Metode pengumpulan data adalah berupa dokumentasi teks hasil interpretasi dari sumber data primer maupun sekunder, reduksi makna, coditing date, observasi dan interview. Adapaun untuk menganalis data yang telah terkumpul dan melihat jenis penelitian ini adalah bersifat deskriptif kualitatif. Maka analisis datanya menggunakan model analisis isi (content analysis) terhadap teks yang menjadi objek dalam penelitian? ${ }^{7}$.

\section{HASIL DAN PEMBAHASAN}

Karakter secara etimologis berasal dari bahasa Yunani "charassein" yang berarti mengukir. Karakter diibaratkan mengukir batu permata atau permukaan

\footnotetext{
${ }^{6}$ Fristiana Irinia, Metode Penelitian Terapan (Yogyakarta: Parama Ilmu, 2017), 100.

${ }^{7}$ Abbas Tashakkori and Charles Teddlie, "Mixed Methodology Mengombinasikan Pendekatan Kualitatif Dan Kuantitatif, Terj," Budi Puspa Priadi. Yogyakarta: Pustaka Pelajar, 2010, 200.
}

besi yang keras ${ }^{8}$. Dalam Kamus Besar Bahasa Indonesia karakter memiliki arti "bawaan, hati, jiwa, kepribadian, budi pekerti, perilaku, personalitas, sifat, tabiat, temperamen, watak"9. Sedangkan karakter dalam bahasa Arab memiliki padanan kata yaitu, khuluq, mizaj, sajiyyah, thab'u, thabi'ah yang berarti budi pekerti, tabiat, atau watak $^{10}$. Dengan demikian dapat diketahui orang berkarakter adalah orang yang memiliki kepribadian dan ciri khas budi pekerti tertentu yang menjadi "tanda ukir" bagi pemiliknya.

Thomas Lickona secara sederhana ada tiga hal penting dalam pendidikan karakter, yaitu: unsur knowing the good (mengetahui kebaikan), loving the good (mencintai kebaikan), dan acting the good (melakukan kebaikan). Jika ingin disimbolkan secara anatomis, ketiga hal tersebut ingin mengatakan sebagai berikut. Pertama, pendidikan karakter mesti mengembangkan otak manusia sebagai salah satu cara untuk mengolah informasi, memahami, dan memaknai realitas di dalam diri dan di luar dirinya. Kedua, pendidikan karakter mesti memaksimalkan fungsi tangan dan kaki sebagai sebuah tindakan bermakna. Ketiga, pendidikan karakter mesti menumbuhkan rasa indah, nyaman,

\footnotetext{
${ }^{8}$ Sri Judiani, “Implementasi Pendidikan Karakter Di Sekolah Dasar Melalui Penguatan Pelaksanaan Kurikulum," Jurnal Pendidikan Dan Kebudayaan 16, no. 9 (2010): 283.

${ }^{9}$ Departemen Pendidikan Nasional, Kamus Besar Bahasa Indonesia (Jakarta: Balai Pustaka, 2008), 445.

10 Ahmad Warson Al-Munawwir, Kamus AlMunawwir Arab-Indonesia Terlengkap (Yogyakarta: Pustaka Progressif, 1997), 838.
} 
mantap dalam hati karena ia tahu bahwa apa yang dilakukannya itu bermakna dan membuatnya bahagia. Bagi Lickona, prinsip teoritis praksis pendidikan karakter adalah apa yang telah ditegaskan oleh Aristoteles ${ }^{11}$.

"virtues are not mere tought but habits we develop by performing virtuos action. Acting on that principle, character educators help students perform virtuous acts repeteadly-until it becomes easy for them to do so and unnatural for them to do the opposite".

Menurut Ki Hajar Dewantara, pendidikan karakter itu terjadi karena perkembangan dasar yang telah kena pengaruh pengajaran. Perkembangan karakter seseorang tergantung pada bakat awalnya dan pengaruh pendidikan yang dialami selanjutnya, sehingga menjadi watak yang tetap pada diri orang tersebut ${ }^{12}$. Selanjutnya beliau memberi definisi mendidik adalah sebagai "berdaya upaya dengan sengaja untuk memajukan hidup tumbuhnya budi pekerti dan badan anak dengan jalan pengajaran, teladan dan pembiasaan". Selain itu, untuk membaca konsep pendidikan karakter Ki Hajar Dewantara adalah melalui semboyan yang dilontarkan beliau yaitu "tut wuri hanadayani" (dari belakang seorang guru harus bisa memberikan dorongan dan arahan), ing madya mangun karsa (di tengah atau di antara murid, pendidik harus menciptakan prakarsa dan ide), dan

\footnotetext{
11 Koesoema, Pendidikan Karakter Utuh Dan Menyeluruh Edisi Revisi, 158.

12 Suparno, Pendidikan Karakter Di Sekolah, 28.
}

ing ngarsa sung tulada (di depan, seorang pendidik harus memberi teladan atau contoh tindakan baik) ${ }^{13}$. Dengan demikian dapat dikatakan, Ki Hajar Dewantara mencoba mengaktualisasikan pendidikan karakter tidak hanya saat mengajar saja akan tetapi di luar jam mengajarpun nilai pendidikan karakter itu tetap dibiasakan.

\section{Identifikasi Nilai-Nilai Karakter dalam Buku Siswa Mapel PAdBP Sekolah Dasar}

Berdasarkan hasil penelitian, nilai-nilai karakter yang muncul secara eksplisit pada buku siswa kelas I mapel PAdBP sekolah dasar adalah kasih sayang, gemar membaca, berkata yang baik, hormat dan patuh, bersyukur, pemaaf, jujur, dan percaya diri. Nilai karakter yang muncul pada buku siswa kelas II adalah jujur, kerjasama, tolong menolong, bersih dan sehat, peduli, berani, disiplin, kasih sayang dan damai. Sedangkan pada buku siswa kelas III nilai karakter yang muncul yaitu percaya diri, tanggungjawab, tawaduk, peduli, ikhlas, mohon pertolongan, dan bersyukur.

\footnotetext{
13 Y. Suyitno, "Tokoh-Tokoh Pendidikan Dunia: Dari Dunia Timur, Timur Tengah Dan Barat," Sekolah Pascasarjana Universitas Pendidikan Indonesia, 2009, 14-15.
} 
Sementara dalam buku siswa kelas IV nilai karakter yang muncul adalah jujur, amanah, hormat dan patuh, santun, menghargai, gemar membaca, pantang menyerah, rendah hati dan hemat. Selanjutnya nilai karakter dalam buku siswa kelas V yang dimunculkan adalah jujur, hormat dan patuh, menghargai, sederhana dan ikhlas. Sementara dalam buku siswa kelas VI nilai karakter yang muncul adalah menghargai, mencintai keindahan, simpati, toleran, hidup rukun, hormat dan patuh.

Tabel 4.1. Buku siswa kelas I

\begin{tabular}{|c|c|c|c|c|c|c|}
\hline No & $\begin{array}{c}\text { Judul } \\
\text { Pelajara } \\
\text { n }\end{array}$ & $\begin{array}{l}\text { Reli } \\
\text { gius }\end{array}$ & $\begin{array}{c}\text { Nasio } \\
\text { nalis }\end{array}$ & $\begin{array}{c}\text { Integr } \\
\text { itas }\end{array}$ & $\begin{array}{c}\text { Man } \\
\text { diri }\end{array}$ & $\begin{array}{l}\text { Gotong } \\
\text { Royong }\end{array}$ \\
\hline 1 & $\begin{array}{l}\text { Kasih } \\
\text { Sayang }\end{array}$ & $\checkmark$ & $\checkmark$ & & $\checkmark$ & $\checkmark$ \\
\hline 2 & $\begin{array}{l}\text { Aku } \\
\text { Cinta al- } \\
\text { Qur'an }\end{array}$ & $\checkmark$ & & & $\checkmark$ & $\checkmark$ \\
\hline 3 & $\begin{array}{l}\text { Iman } \\
\text { Kepada } \\
\text { Allah } \\
\text { SWT. }\end{array}$ & $\checkmark$ & & & $\checkmark$ & \\
\hline 4 & $\begin{array}{l}\text { Bersih } \\
\text { itu Sehat }\end{array}$ & $\checkmark$ & $\checkmark$ & & $\checkmark$ & $\checkmark$ \\
\hline 5 & $\begin{array}{l}\text { Cinta } \\
\text { Nabi } \\
\text { dan } \\
\text { Rasul }\end{array}$ & $\checkmark$ & & $\checkmark$ & & \\
\hline 6 & $\begin{array}{l}\text { Ayo } \\
\text { Belajar }\end{array}$ & $\checkmark$ & & $\checkmark$ & & \\
\hline 7 & $\begin{array}{l}\text { Ayo } \\
\text { Belajar } \\
\text { Al- } \\
\text { Qur'an }\end{array}$ & $\checkmark$ & & & & $\checkmark$ \\
\hline 8 & $\begin{array}{l}\text { Allah } \\
\text { Maha } \\
\text { Raja }\end{array}$ & $\checkmark$ & & & $\checkmark$ & \\
\hline 9 & $\begin{array}{l}\text { Ayo Kita } \\
\text { Salat }\end{array}$ & $\checkmark$ & & $\checkmark$ & & \\
\hline 10 & $\begin{array}{l}\text { Perilaku } \\
\text { terpuji }\end{array}$ & $\checkmark$ & & $\checkmark$ & $\checkmark$ & \\
\hline$*$ & Jumlah & 10 & 2 & 4 & 6 & 4 \\
\hline
\end{tabular}

Setelah diketahui berbagai karakteristik nilai karakter yang muncul dari masing-masing buku siswa mapel
PAdBP kelas I sampai dengan kelas VI. Tahap berikutnya adalah pemetaan dan pemilihan nilai karakter mana saja yang masuk ke dalam lima nilai penguatan pendidikan karakter (PPK) sebagaimana yang telah dicanangkan oleh pemerintah ${ }^{14}$. Kelima item nilai karakter yang dimaksud adalah nilai religius, nasionalis, integritas, mandiri, gotong royong. Berikut adalah pembahasan mengenai pemetaan lima nilai penguatan pendidikan karakter yang muncul pada buku siswa mapel PAdBP sekolah dasar:

Tabel 4.2. Buku siswa kelas II

\begin{tabular}{|c|c|c|c|c|c|c|}
\hline No & $\begin{array}{c}\text { Judul } \\
\text { Pelajaran }\end{array}$ & $\begin{array}{c}\text { Religi } \\
\text { us }\end{array}$ & $\begin{array}{c}\text { Nasio } \\
\text { nalis }\end{array}$ & $\begin{array}{c}\text { Integr } \\
\text { itas }\end{array}$ & $\begin{array}{l}\text { Man } \\
\text { diri }\end{array}$ & $\begin{array}{l}\text { Gotong } \\
\text { Royong }\end{array}$ \\
\hline 1 & $\begin{array}{l}\text { Nabi } \\
\text { Muhamma } \\
\text { d saw. } \\
\text { Teladanku }\end{array}$ & $\checkmark$ & & $\checkmark$ & $\checkmark$ & $\checkmark$ \\
\hline 2 & $\begin{array}{l}\text { Asyik Bisa } \\
\text { Membaca } \\
\text { Al-Qur'an }\end{array}$ & $\checkmark$ & & & $\checkmark$ & \\
\hline 3 & $\begin{array}{l}\text { Allah } \\
\text { Maha } \\
\text { Pencipta }\end{array}$ & $\checkmark$ & & & & $\checkmark$ \\
\hline 4 & $\begin{array}{l}\text { Perilaku } \\
\text { Terpuji }\end{array}$ & $\checkmark$ & $\checkmark$ & $\checkmark$ & & $\checkmark$ \\
\hline 5 & $\begin{array}{l}\text { Hidup } \\
\text { Bersih dan } \\
\text { Sehat }\end{array}$ & $\checkmark$ & $\checkmark$ & & & $\checkmark$ \\
\hline 6 & $\begin{array}{l}\text { Ayo } \\
\text { Berwudu }\end{array}$ & $\checkmark$ & & & $\checkmark$ & $\checkmark$ \\
\hline 7 & Berani & $\checkmark$ & & $\checkmark$ & $\checkmark$ & $\checkmark$ \\
\hline 8 & $\begin{array}{l}\text { Senang } \\
\text { Bisa } \\
\text { Membaca } \\
\text { Al-Qur'an }\end{array}$ & $\checkmark$ & & $\checkmark$ & $\checkmark$ & $\checkmark$ \\
\hline 9 & $\begin{array}{l}\text { Allah } \\
\text { Maha Suci }\end{array}$ & $\checkmark$ & $\checkmark$ & $\checkmark$ & & $\checkmark$ \\
\hline 10 & $\begin{array}{l}\text { Kasih } \\
\text { Sayang }\end{array}$ & $\checkmark$ & $\checkmark$ & $\checkmark$ & & $\checkmark$ \\
\hline 11 & $\begin{array}{l}\text { Ayo Kita } \\
\text { Salat }\end{array}$ & $\checkmark$ & & & $\checkmark$ & $\checkmark$ \\
\hline * & Jumlah & 11 & 4 & 6 & 6 & 10 \\
\hline
\end{tabular}

\footnotetext{
14 Peraturan Presiden No. 87, "Penguatan Pendidikan Karakter” (Jakarta, 2017).
} 
Building Students' Critical Thinking....| 163

Tabel 4.3. Buku siswa kelas III

\begin{tabular}{|c|c|c|c|c|c|c|}
\hline $\begin{array}{l}\mathbf{N} \\
\mathbf{0}\end{array}$ & $\begin{array}{c}\text { Judul } \\
\text { Pelajaran }\end{array}$ & $\begin{array}{l}\text { Reli } \\
\text { gius }\end{array}$ & $\begin{array}{c}\text { Nasio } \\
\text { nalis }\end{array}$ & $\begin{array}{c}\text { Integr } \\
\text { itas }\end{array}$ & $\begin{array}{l}\text { Man } \\
\text { diri }\end{array}$ & $\begin{array}{l}\text { Gotong } \\
\text { Royong }\end{array}$ \\
\hline 1 & $\begin{array}{l}\text { Nabi } \\
\text { Muhamma } \\
\text { d saw. } \\
\text { Panutanku }\end{array}$ & $\checkmark$ & & & $\checkmark$ & $\checkmark$ \\
\hline 2 & $\begin{array}{l}\text { Senangnya } \\
\text { Belajar } \\
\text { surat an- } \\
\text { Nasr }\end{array}$ & $\checkmark$ & & & $\checkmark$ & $\checkmark$ \\
\hline 3 & $\begin{array}{l}\text { Meyakini } \\
\text { Allah } \\
\text { Maha Esa } \\
\text { dan Maha } \\
\text { Pemberi }\end{array}$ & $\checkmark$ & & $\checkmark$ & & $\checkmark$ \\
\hline 4 & $\begin{array}{l}\text { Hidup } \\
\text { Tenang } \\
\text { dengan } \\
\text { Berperilak } \\
\text { u Terpuji }\end{array}$ & $\checkmark$ & $\checkmark$ & $\checkmark$ & $\checkmark$ & $\checkmark$ \\
\hline 5 & $\begin{array}{l}\text { Salat } \\
\text { Kewajiban } \\
\text { ku }\end{array}$ & $\checkmark$ & & $\checkmark$ & $\checkmark$ & $\checkmark$ \\
\hline 6 & $\begin{array}{l}\text { Kisah } \\
\text { Keteladan } \\
\text { an Nabi } \\
\text { Yusuf a.s. } \\
\text { dan Nabi } \\
\text { Syu'aib a.s. }\end{array}$ & $\checkmark$ & $\checkmark$ & $\checkmark$ & $\checkmark$ & $\checkmark$ \\
\hline 7 & $\begin{array}{l}\text { Hati } \\
\text { Tenteram } \\
\text { dengan } \\
\text { Berperilak } \\
\text { u Baik }\end{array}$ & $\checkmark$ & $\checkmark$ & & & $\checkmark$ \\
\hline 8 & $\begin{array}{l}\text { Belajar } \\
\text { Surat al- } \\
\text { Kausar }\end{array}$ & $\checkmark$ & & & $\checkmark$ & $\checkmark$ \\
\hline 9 & $\begin{array}{l}\text { Meyakini } \\
\text { Allah } \\
\text { Maha } \\
\text { Mengetah } \\
\text { ui dan } \\
\text { Maha } \\
\text { Mendenga } \\
\text { r }\end{array}$ & $\checkmark$ & & $\checkmark$ & & $\checkmark$ \\
\hline 10 & $\begin{array}{l}\text { Bersyukur } \\
\text { kepada } \\
\text { Allah swt. }\end{array}$ & $\checkmark$ & & & $\checkmark$ & $\checkmark$ \\
\hline 11 & $\begin{array}{l}\text { Zikir dan } \\
\text { Do'a } \\
\text { setelah } \\
\text { Salat }\end{array}$ & $\checkmark$ & $\checkmark$ & & & $\checkmark$ \\
\hline 12 & $\begin{array}{l}\text { Kisah } \\
\text { Keteladan } \\
\text { an Nabi } \\
\text { Ibrahim } \\
\text { a.s. dan } \\
\text { Nabi } \\
\text { Ismail a.s. }\end{array}$ & $\checkmark$ & & $\checkmark$ & $\checkmark$ & $\checkmark$ \\
\hline$*$ & Jumlah & 12 & 4 & 6 & 8 & 12 \\
\hline
\end{tabular}

Tabel 4.4. Buku siswa kelas IV

\begin{tabular}{|c|c|c|c|c|c|c|}
\hline No & $\begin{array}{c}\text { Judul } \\
\text { Pelajaran }\end{array}$ & $\begin{array}{l}\text { Reli } \\
\text { gius }\end{array}$ & $\begin{array}{c}\text { Nasio } \\
\text { nalis }\end{array}$ & $\begin{array}{c}\text { Integr } \\
\text { itas }\end{array}$ & $\begin{array}{l}\text { Man } \\
\text { diri }\end{array}$ & $\begin{array}{l}\text { Gotong } \\
\text { Royong }\end{array}$ \\
\hline 1 & $\begin{array}{l}\text { Mari } \\
\text { Belajar Q.S } \\
\text { al-Falaq }\end{array}$ & $\checkmark$ & & & $\checkmark$ & $\checkmark$ \\
\hline 2 & $\begin{array}{l}\text { Beriman } \\
\text { Kepada } \\
\text { Allah dan } \\
\text { Rasul-Nya }\end{array}$ & $\checkmark$ & & $\checkmark$ & & \\
\hline 3 & $\begin{array}{l}\text { Aku Anak } \\
\text { Salih }\end{array}$ & $\checkmark$ & & $\checkmark$ & & \\
\hline 4 & $\begin{array}{l}\text { Bersih itu } \\
\text { Sehat }\end{array}$ & $\checkmark$ & & & $\checkmark$ & \\
\hline 5 & $\begin{array}{l}\text { Aku Cinta } \\
\text { Nabi dan } \\
\text { Rasul }\end{array}$ & $\checkmark$ & & & $\checkmark$ & \\
\hline 6 & $\begin{array}{l}\text { Mari } \\
\text { Belajar Q.S } \\
\text { al-Fil }\end{array}$ & $\checkmark$ & & & $\checkmark$ & $\checkmark$ \\
\hline 7 & $\begin{array}{l}\text { Beriman } \\
\text { kepada } \\
\text { Malaikat } \\
\text { Allah }\end{array}$ & $\checkmark$ & $\checkmark$ & $\checkmark$ & $\checkmark$ & $\checkmark$ \\
\hline 8 & $\begin{array}{l}\text { Mari } \\
\text { Berperilak } \\
\text { u Terpuji }\end{array}$ & $\checkmark$ & & $\checkmark$ & $\checkmark$ & \\
\hline 9 & $\begin{array}{l}\text { Mari } \\
\text { Melaksana } \\
\text { kan Salat }\end{array}$ & $\checkmark$ & & $\checkmark$ & $\checkmark$ & $\checkmark$ \\
\hline 10 & $\begin{array}{l}\text { Kisah } \\
\text { Keteladan } \\
\text { an Wali } \\
\text { Songo }\end{array}$ & $\checkmark$ & $\checkmark$ & & & $\checkmark$ \\
\hline * & Jumlah & 10 & 2 & 5 & 7 & 5 \\
\hline
\end{tabular}


Tabel 4.5. Buku siswa kelas $\mathrm{V}$

\begin{tabular}{|c|c|c|c|c|c|c|}
\hline $\begin{array}{l}\mathbf{N} \\
\mathbf{0}\end{array}$ & $\begin{array}{c}\text { Judul } \\
\text { Pelajaran }\end{array}$ & $\begin{array}{l}\text { Reli } \\
\text { gius }\end{array}$ & $\begin{array}{r}\text { Nasio } \\
\text { nalis }\end{array}$ & $\begin{array}{c}\text { Integr } \\
\text { itas }\end{array}$ & $\begin{array}{l}\text { Man } \\
\text { diri }\end{array}$ & $\begin{array}{l}\text { Gotong } \\
\text { Royong }\end{array}$ \\
\hline 1 & $\begin{array}{l}\text { Mari } \\
\text { Belajar al- } \\
\text { Qur'an } \\
\text { surat at- } \\
\text { Tin }\end{array}$ & $\checkmark$ & & $\checkmark$ & $\checkmark$ & $\checkmark$ \\
\hline 2 & $\begin{array}{l}\text { Mengenal } \\
\text { Nama } \\
\text { Allah dan } \\
\text { Kitab- } \\
\text { Kitab-Nya }\end{array}$ & $\checkmark$ & $\checkmark$ & $\checkmark$ & $\checkmark$ & $\checkmark$ \\
\hline 3 & $\begin{array}{l}\text { Cita-citaku } \\
\text { Menjadi } \\
\text { Anak Salih }\end{array}$ & $\checkmark$ & $\checkmark$ & $\checkmark$ & & $\checkmark$ \\
\hline 4 & $\begin{array}{l}\text { Bulan } \\
\text { Ramadan } \\
\text { yang } \\
\text { Indah }\end{array}$ & $\checkmark$ & & $\checkmark$ & & $\checkmark$ \\
\hline 5 & $\begin{array}{l}\text { Rasul } \\
\text { Allah } \\
\text { Idolaku }\end{array}$ & $\checkmark$ & & $\checkmark$ & $\checkmark$ & $\checkmark$ \\
\hline 6 & $\begin{array}{l}\text { Mari } \\
\text { Belajar al- } \\
\text { Qur'an } \\
\text { surat al- } \\
\text { Ma'un }\end{array}$ & $\checkmark$ & & & $\checkmark$ & $\checkmark$ \\
\hline 7 & $\begin{array}{l}\text { Mari } \\
\text { Mengenal } \\
\text { Rasul- } \\
\text { Rasul } \\
\text { Allah Swt. }\end{array}$ & $\checkmark$ & $\checkmark$ & $\checkmark$ & $\checkmark$ & $\checkmark$ \\
\hline 8 & $\begin{array}{l}\text { Mari } \\
\text { Hidup } \\
\text { Sederhana } \\
\text { dan Ikhlas }\end{array}$ & $\checkmark$ & & $\checkmark$ & $\checkmark$ & \\
\hline 9 & $\begin{array}{l}\text { Indahnya } \\
\text { Salat } \\
\text { Tarawih } \\
\text { dan } \\
\text { Tadarus } \\
\text { al-Qur'an }\end{array}$ & $\checkmark$ & & & $\checkmark$ & $\checkmark$ \\
\hline 10 & $\begin{array}{l}\text { Kisah } \\
\text { Teladan } \\
\text { Lukman }\end{array}$ & $\checkmark$ & & $\checkmark$ & & \\
\hline$*$ & Jumlah & 10 & 3 & 8 & 7 & 8 \\
\hline
\end{tabular}

Tabel 4.6. Buku siswa kelas VI

\begin{tabular}{|c|c|c|c|c|c|c|}
\hline $\begin{array}{l}\mathbf{N} \\
\mathbf{o}\end{array}$ & $\begin{array}{c}\text { Judul } \\
\text { Pelajaran }\end{array}$ & $\begin{array}{l}\text { Reli } \\
\text { gius }\end{array}$ & $\begin{array}{c}\text { Nasio } \\
\text { nalis }\end{array}$ & $\begin{array}{c}\text { Integr } \\
\text { itas }\end{array}$ & $\begin{array}{c}\text { Man } \\
\text { diri }\end{array}$ & $\begin{array}{l}\text { Gotong } \\
\text { Royong }\end{array}$ \\
\hline 1 & $\begin{array}{l}\text { Indahnya } \\
\text { Saling } \\
\text { Menghor } \\
\text { mati }\end{array}$ & $\checkmark$ & $\checkmark$ & & $\checkmark$ & $\checkmark$ \\
\hline 2 & $\begin{array}{l}\text { Ketika } \\
\text { Bumi } \\
\text { Berhenti } \\
\text { Berputar }\end{array}$ & $\checkmark$ & & & $\checkmark$ & $\checkmark$ \\
\hline 3 & $\begin{array}{l}\text { Indahnya } \\
\text { Nama- } \\
\text { Nama } \\
\text { Allah Swt. }\end{array}$ & $\checkmark$ & $\checkmark$ & $\checkmark$ & & $\checkmark$ \\
\hline 4 & $\begin{array}{l}\text { Ayo, } \\
\text { Membayar } \\
\text { Zakat }\end{array}$ & $\checkmark$ & $\checkmark$ & $\checkmark$ & & $\checkmark$ \\
\hline 5 & $\begin{array}{l}\text { Keteladan } \\
\text { an } \\
\text { Rasulullah } \\
\text { saw. dan } \\
\text { Sahabatny } \\
\text { a }\end{array}$ & $\checkmark$ & $\checkmark$ & $\checkmark$ & $\checkmark$ & $\checkmark$ \\
\hline 6 & $\begin{array}{l}\text { Indahnya } \\
\text { Saling } \\
\text { Membantu }\end{array}$ & $\checkmark$ & $\checkmark$ & & & $\checkmark$ \\
\hline 7 & $\begin{array}{l}\text { Menerima } \\
\text { Qada dan } \\
\text { Qadar }\end{array}$ & $\checkmark$ & & $\checkmark$ & $\checkmark$ & $\checkmark$ \\
\hline 8 & $\begin{array}{l}\text { Senangnya } \\
\text { Berakhlak } \\
\text { Terpuji }\end{array}$ & $\checkmark$ & $\checkmark$ & $\checkmark$ & & $\checkmark$ \\
\hline 9 & $\begin{array}{l}\text { Ayo, } \\
\text { Berinfak } \\
\text { dan } \\
\text { Bersedeka } \\
\text { h }\end{array}$ & $\checkmark$ & & $\checkmark$ & & $\checkmark$ \\
\hline 10 & $\begin{array}{l}\text { Senangnya } \\
\text { menelada } \\
\text { ni para } \\
\text { Nabi dan } \\
\text { Ashabul } \\
\text { Kahfi }\end{array}$ & $\checkmark$ & & $\checkmark$ & & $\checkmark$ \\
\hline$*$ & Jumlah & 10 & 6 & 7 & 4 & 10 \\
\hline
\end{tabular}

Berdasarkan pemetaan tabel di atas dapat disimpulkan bahwa lima nilai penguatan pendidikan karakter yang muncul pada buku siswa mapel PAdBP sekolah dasar dapat dipersentasekan dengan skor perolehan nilai religius sebanyak $31 \%$, nilai nasionalis $10 \%$, nilai integritas 17 $\%$, nilai mandiri $18 \%$, dan nilai gotong royong $23 \%$. Ini artinya nilai religius sangat mendominasi pada buku siswa mapel PAdBP tingkat sekolah dasar, disusul urutan berikutnya adalah nilai gotong royong, mandiri, integritas, dan nasionalis. 


\section{KESIMPULAN}

Setelah dilakukan penelitian terhadap buku siswa mapel PAdBP (Pendidikan Agama Islam dan Budi Pekerti) tingkat sekolah dasar dapat disimpulkan sebagaimana berikut:Nilai karakter yang muncul dalam buku siswa mapel PAdBP tingkat sekolah dasar adalah nilai religius, kasih sayang, peduli, tanggungjawab, mandiri, gemar membaca, hormat, patuh, jujur, gotong royong, berani, disiplin, percaya diri, rendah hati, integritas, bersyukur, ikhlas, menghargai, santun, kerja keras, hidup bersih dan sehat, sederhana, hidup rukun, berbaik sangka, simpati, berkata yang baik, pemaaf, tolong menolong, cinta damai, mohon pertolongan, amanah, pantang menyerah, hemat, mencintai keindahan, dan toleran (menghargai perbedaan).

Strategi penanaman lima nilai penguatan pendidikan karakter dalam buku siswa mapel PAdBP sekolah dasar yaitu menghasilkan persentase yang bebeda-beda volume penekanannya. Nilai religius menjadi sangat dominan dengan persentase $31 \%$. Ini artinya semua pelajaran dari kelas satu sampai dengan kelas enam nilai religius selalu mendapat tempat utama untuk selalu ditanamkan dalam diri peserta didik. Nilai karakter penekanan terbesar kedua adalah nilai gotong royong dengan skor persentase 24\%. Disusul nilai karakter penekanan ketiga yaitu nilai mandiri dengan persentase 18\%. Urutan keempat adalah nilai integritas dengan persentase $17 \%$, dan urutan kelima adalah nilai nasional sebanyak $10 \%$. Hasil dari persentase strategi penanaman lima nilai penguatan pendidikan karakter (PPK) pada buku siswa mapel PAdBP sekolah dasar tersebut apabila dianalisis menggunakan 'kacamata' teori pendidikan karakter Thomas Lickona dihasilkan sebuah temuan. Temuan itu adalah ada sebagian proses pembelajaran yang tergambarkan dalam isi buku siswa PAdBP sekolah dasar belum terpenuhi sepenuhnya dengan teori yang diharapkan oleh Lickona. Sedangkan jika dilihat dengan menggunakan "kacamata" teori pendidikan karakter sebagaimana yang diharapkan Ki Hajar Dewantara, deskripsi proses pembelajaran dalam menanamkan lima nilai penguatan pendidikan karakter (PPK) pada buku siswa mapel PAdBP sekolah dasar mulai dari kelas I sampai dengan VI tersebut sudah terpenuhi seluruhnya. 


\section{Daftar Pustaka}

Al-Munawwir, Ahmad Warson. Kamus Al-

Munawwir Arab-Indonesia

Terlengkap. Yogyakarta: Pustaka

Progressif, 1997.

Irinia, Fristiana. Metode Penelitian

Terapan. Yogyakarta: Parama Ilmu, 2017.

Judiani, Sri. "Implementasi Pendidikan

Karakter Di Sekolah Dasar Melalui

Penguatan Pelaksanaan

Kurikulum." Jurnal Pendidikan Dan

Kebudayaan 16, no. 9 (2010): 280289.

Kemendikbud. Hand Out Bahan Pelatihan

Materi Umum Dan Materi Pokok

Sekolah Dasar. Direktorat

Kemendikbud, 2016.

Koesoema, Doni. Pendidikan Karakter

Utuh Dan Menyeluruh Edisi Revisi.

Yogyakarta: PT Kanisius, 2015.

Nasional, Departemen Pendidikan. Kamus

Besar Bahasa Indonesia. Jakarta:

Balai Pustaka, 2008.

No. 87, Peraturan Presiden. "Penguatan

Pendidikan Karakter." Jakarta,

2017.
"Ribuan Buku Pendidikan Agama Islam

Ditarik Di Labuhanbatu |

Republika Online." Accessed

September 5, 2019.

https://nasional.republika.co.id/b

erita/onxtnx384/ribuan-buku-

pendidikan-agama-islam-ditarik-

di-labuhanbatu.

Suparno, Paul. Pendidikan Karakter Di Sekolah. Yogyakarta: Kanisius, 2015.

Suyitno, Y. "Tokoh-Tokoh Pendidikan Dunia: Dari Dunia Timur, Timur Tengah Dan Barat." Sekolah Pascasarjana Universitas Pendidikan Indonesia, 2009.

Tashakkori, Abbas, and Charles Teddlie. "Mixed Methodology Mengombinasikan Pendekatan Kualitatif Dan Kuantitatif, Terj." Budi Puspa Priadi. Yogyakarta: Pustaka Pelajar, 2010. 